\title{
Using 4MAT strategy to develop preparatory school pupils' reading comprehension and critical thinking skills
}

\author{
Dr: Marwa Mourad Saleh \\ A lecturer at Department of Curriculum and \\ Instruction(EFL) \\ Faculty of Education, Fayoum University, Egypt
}

Abstract

The Present study aimed at developing preparatory school pupils' reading and critical thinking skills through the use of 4MAT strategy. Participants of the study were 60 third year Hassan Idrees preparatory school pupils' at Fayoum governorate. They were randomly assigend to two groups: experimental $(\mathrm{N}=30)$ and control $(\mathrm{N}=30)$. The researcher prepared a reading test, a scale and a manual. Having pre administered the reading test and critical thinking scale ,the experimental group was taught using 4MAT strategy. The same instruments were administered at the end of the treatment. The results showed that the use of 4MAT strategy proved to be effective in developing preparatory school pupils' reading and their critical thinking skills. The study concluded with some recommendations and suggestions for the pupils, teachers and curriculum designers. Also, suggestions for further research were provided.

Keywords: 4MAT strategy, reading skills, critical thinking skills, preparatory school pupils.

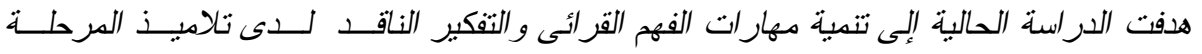

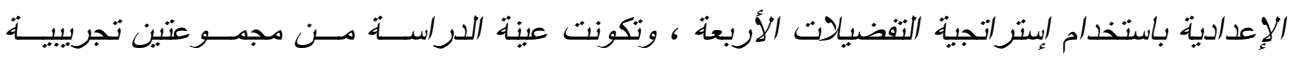

$$
\begin{aligned}
& \text { وضابطه اشتنلت كل واحده على (.r. ) طالبًا من طلاب الصف الثالث الإعدادى بمدرسة حسن إدريـس } \\
& \text { الإعدادية بدحافظة الفيوم.وقامت الباحثة بإعداد اختبار لمهارات القراءة.كما قامت بإعداد مقياس للتفكيـر }
\end{aligned}
$$

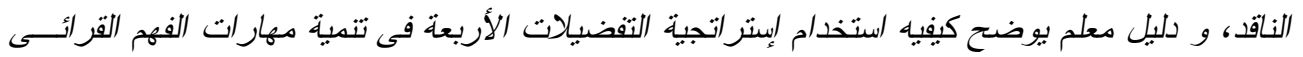

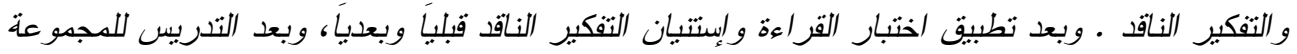

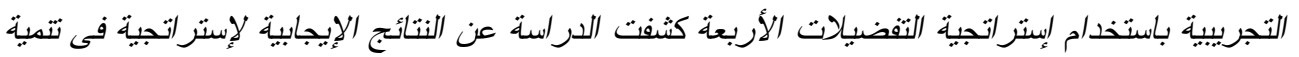

$$
\begin{aligned}
& \text { مهارات الفهم القرائى والتفكير الناقد لدى أفراد الدجموعة التجريبية. واختتمت الباحثة الدراســـة بتقـــيم }
\end{aligned}
$$

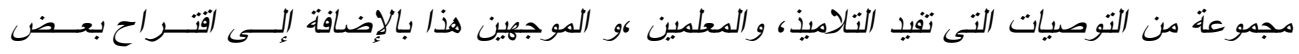

$$
\begin{aligned}
& \text { الدراسات و البحوث المستقبلية. } \\
& \text { الكلمات المفتاحية: إستر اتيجية التفضيلات الأربعة ـ مهار ات الفهم القرائىـ مهار ات التفكير الناقد ـ تلاميذ } \\
& \text { المرحلة الإعدادية }
\end{aligned}
$$




\section{Introduction}

There are many physiological and psychological differences among individuals. Each individual is unique in his genetic makeup and past experience. Such differences among individuals cause differences in cognitive, emotional and kinesthetic responses to the same teaching method. Thus, a teaching method can help some pupils learn, while being ineffective for some others ( Tezcan \& Guvenc, 2017).

One of the individual differences that affect learning is learning styles which can be defined as the best method of learning for each learner. In order to ensure equity in learning for all students, much attention has focused on learning styles and their impact on the teaching and learning process (Nicoll- senft \& Seider , 2010). When students were taught through their preferred learning style they show improvement in their attitudes towards subject, better recognition for diversity, significant enhancement of academic achievement, and more self commitment for homework ( Irfan ;Alnaufadi \& Brisha, 2016).

The 4MAT (4 Mode Application Techniques) strategy was created by Bernice McCarthy in the 1970s. This strategy transforms the concept of learning styles into educational strategies and is based on the constructionist approach. The strategy makes use of the four learning styles examined by Kolb (1984). In this strategy, individuals' perceive and process knowledge in different ways. Individuals methods of perceiving knowledge are based on concrete experiences and abstract conceptualizations. When learning new things, some individuals consider their concrete experiences directly and perceive by sensing and feeling. On the other hand, other individuals process or organize knowledge by observing and others by doing and practicing. (Şeker \& Övez, 2018).

4MAT strategy depends on the experimental teaching theory in the outcomes of Kolb's research (1984) of the brain hemispheres (Uyangor, 2012). A person favors the right or the left hemispheres in the brain for processing new information. The learner whose operational tendency is to the right hemisphere comprehends images, seeks patterns, creates metaphors, and is simultaneous in nature. The learner who prefers the left- brain hemisphere operates, with analysis, uses languages, abstracts experiences and has number sense. However, a learner does not use one hemisphere in its entirety. He / she switches from one hemisphere to the other based on what the situation requires (Bul Bul \& Ossoy, 2015).

\section{Definition of 4MAT strategy}

According to Nicoll- Senft and Seedier (2010) and Kutay (2006) 4MAT identifies four interrelated learning styles based on a continuum of how learners perceive and process new information. A learner's individual learning style results from where he/she naturally falls on such continuum. McCarthy has identified 
these learning styles as imaginative learners, analytic learners, common sense learners and dynamic learners.

Imaginative learners learn best through personal experience. They benefit from opportunities to find meaning in what they are learning and they enjoy discussing their beliefs, feelings, and opinions with others. They are reflective in nature and learn through dialogue. Their priority in the classroom is individual student development. Cooperative learning, brainstorming, and integration of different contents such as science with writing models are effective for such learners.

Analytic learners approach learning in a logical, organized manner by examining details and specifics. They often excel in a traditional classroom setting and enjoy reflecting on new ideas and connecting new learning to other information they know to be true. Also, they are logical in nature and enjoy formulating theories and models. They strive for precision and prefer teachers that do so as well . Such learners prefer mostly traditional lectures, independent research, and listening to experts in the subject matter. To best meet their needs, teachers should emphasize introducing the content through well organized and logical lectures, note taking and readings.

Common sense learners learn by doing. They focus on practical applications of new information. They are active learners, preferring to work in the classroom. They dislike assignments that do not have an obvious purpose or application. They learn best when provided with handson, experiential learning opportunities. Such learners prefer the concrete style, experimental activities, hands- on tasks, and kinesthetic experience. Teachers should provide learners with opportunities to practice new skills.

Finally, dynamic learners are active learners they enjoy taking risks and learn primarily through self discovery. They like to connect their learning to things that matter in their lives. They enjoy synthesizing information and applying their learning in new situations. Such learners trust their feelings and also like to teach others. They prefer involvement in any type of independent studies, role - playing and games. Teachers such challenge such students by creating real life learning experiences in the classroom.

According to BulBul and Ozsoy (2015) the 4 MAT strategy sequences the four learning styles in a framework that reflects the learners' natural learning cycle. This cycle starts with the experiences and knowledge a student already has, then it adds new information or insight to be learned. Next, the learner gets a chance to manipulate the new information and finally takes the learned materials and applies it to the world around him/ her and to his/ her life. From this point in the cycle the learners builds a new base from which to relate and begin the cycle again. 


\section{MAT strategy as an eight - stage} instructional cycle

The 4 MAT teaching strategy is an eight - stage instructional cycle. The first quarter includes the first and second steps :"connect" and "examine". The aim of this stage is to make connections between the students' environment and concepts. The essential question at this stage is "Why". The second quarter includes the third and the fourth steps: "imagine" and "define". In this quarter, individuals learn what a concept is. Students analyze their experiences and shape concepts. The essential question at this stage is "What?" The third quarter includes the fifth and the sixth steps "practice" and "extend". In this quarter, students implement the concepts and learning is individualized. The essential question at this stage is "How?" The fourth quarter includes the seventh the eighth steps : "refine" and "integrate". In this quarter, practice and experience are integrated. The essential question of this stage is "If ?" (Şeker \& Övez, 2018). 4MAT teaching strategy respectively gives places to both the right and the left brain activities for each of the four learning styles (Tezcan \& Guvenc, 2017).

\section{Advantages of 4 MAT strategy}

According to Seker and Ovez (2018) and Irfang; Almufadiz and Brisha (2016). 4MAT strategy has several advantages First, it encourages students to develop their own understanding and perceptions. Second, it allows the teaching environment to be organized around targeted concepts and supports the use of different strategies by facilitating an integrated teaching approach. Using different teaching strategies together in an integrated way makes learning more interesting. Third, $t$ is a student- centered strategy. It organizes learning according to the needs of students, and it provides a framework for teachers to plan eight stage learning activities in a systematic cycle. Fourth, it respects student's differences, ensures the transition from subjectivity to objectivity for integrated learning, and improves the holistic thinking style. Fifth, it results in positive attitudes, enhancing of academic achievement and more long - life learning.

\section{Critical thinking skills}

One of the essential thinking skills is critical thinking. There is no consensus among researchers about critical thinking definition. The most commonly used definition is that given by Ennis (1989) as a reasonable, reflective thinking that is focused on deciding what to believe or do. Instead of the simple act of receiving information and accepting it, critical thinking involves an "active" process of thinking and analyzing what is received (Fisher, 2001).

thinking helps learners to improve their abilities of criticizing, questioning, evaluating and reflection (zhang \& Kim, 2018).

Critical thinking ability is not something inborn. It is considered a learnable skill. So, it can be taught to 
learners in the classroom. The ability to think critically constitutes a kind of intelligence which students do not naturally possess, but it is a skill that can be improved and fostered by practice. ( Lakovos, 2011). Critical thinking skills' are no likely to develop spontaneously. Teachers must take a directive role in initiating and guiding critical thinking through providing learners with appropriate materials and activities.

Critical thinking includes both cognitive competencies and personal competencies which interact with each other. Each competency involves different components that are in constant interaction with each another. Cognitive competencies include having the ability to modify, analyze, interpret, examine, synthesize, summarize, and make inferences and generalizations. Personal competencies, on the other hand, include being tolerant of ambiguity, thinking independently, having perseverance, being self confident, motivated, reflective, creative, and curious. ( Fahim \& Pezeshki, 2012).

Significance of critical thinking

According to Zhang and Kim (2018) and Shirkhani and Fahim (2011) critical thinking is of high significance for several reasons. First, it helps language learners take charge of their own thinking, they can monitor and evaluate their own ways of learning more successfully. Second, it expands the learning experience of the learners and makes the language more meaningful for them . Third, it has a high degree of correlation with the learners' achievements, writing ability , language proficiency, oral communication ability and higherorder thinking skills. Fourth, it helps learners to improve their abilities of criticizing , questioning, evaluating and reflection.

\section{Characteristics of critical thinking}

A great body of literature highlights that critical thinkers are those who identify problems and focus on relevant topics and issues, distinguish between valid and invalid inferences and suspend judgments and decisions in the absence of sufficient evidence. They also can understand the difference between logical reasoning and rationalizing, accurately explain their decisions, determine the truth or falsity of assumptions and present reasoned and persuasive arguments. Furthermore, they can distinguish opinions from facts, formulate and ask appropriate questions, listen attentively to others and provide them with appropriate feedback, assess and evaluate statements, have a keen sense of curiosity and are open to criticisms ( Rezaei, Dera Kh Shan \& Bagherka zemi , 2011).

The role of teachers in developing critical thinking skills

Muirhead (2002) identifies essential critical thinking skills including defining and clarifying the problem, identifying central issues or problems, comparing similarities and differences, determining which information is relevant. They also 
include formulating appropriate questions, distinguishing between fact, opinion and reasoned judgment, checking consistency and identifying unstated assumptions.

Teachers can play a vital role in enhancing critical thinking skills. They should be aware of the cognitive and mental processes that constitute critical thinking. They should also be familiar with the tasks, skills, and situations to which these processes are applied. Teachers' use of questions, involving students in discussions on challenging and motivating topics could engage students in meaningful critical thinking processes. Furthermore, a context that supports and values inquiry and a teaching atmosphere that respects different viewpoints are crucial in facilitating students' critical thinking development. Practical techniques as debates, problem - solving tasks, selfassessment and peer- assessment can also be helpful . Finally, teachers' application of critical thinking skills and providing explicit explanation of the importance of critical thinking could help students improve their critical thinking skills. ( Lakovos, 2011, Rezaei, Derakhsho \& Bagherkazemi, 2011).

Ghaemi and Taherian (2011) state that teachers should have the following characteristics to develop learners' critical thinking: be eager and ready to increase their knowledge base, set high expectations for students and create independence They should also have a deep knowledge of the subject matter, possess a good sense of humor, obtain quick and accurate assessment of the students' work. In addition, they should be flexible, provide various techniques for learners to learn, keep students off balance and have the ability to communicate with others.

Zhang and Kim (2018) pointed out that there are three approaches to critical thinking cultivation in classes:1) constructing contrive learning environment through providing students with opportunities to reflect, explore and solve some practical problems in their learning, 2) designing flexible instructional strategies through combining critical thinking cultivation with teaching materials, classroom discussions, homework, extracurricular activities and examinations and 3) adopting formative, seamless assessment through guiding students to develop regular reflections to assess their learning experience.

\section{Studies related to 4 MAT strategy and critical thinking}

To the researcher's knowledge ,there were two studies reviewed.They were Khaoanurak (2015) and Şeker and Övez (2018).

Khaoanurak (2015) investigated the use of 4MAT strategy in improving students' critical thinking in EFL class. Participants of the study were 50 students in Matthayomsueksa at The Prince Royal's College in Chiang Mai Province. A critical thinking test, a questionnaire, an interview schedule and an observation form were used to collect data. Results showed that 4MAT strategy 
improved students' critical thinking and motivated them to learn English.

$$
\text { Şeker and Övez (2018) }
$$

examined the effectiveness of a model developed based on the 4MAT teaching model and the interdisciplinary concept models in developing the students' level of attainment of learning acquisitions and achievement. Participants of the study were 65 primary school students .A learning style inventory and an achievement test were used to collect data. Results showed that the attainment level of students and their mean scores significantly favored the experimental group. Also, the proposed strategy helped experimental group students develop their critical thinking skills in comparison to the control group students.

\section{Reading comprehension skills}

Reading is one of the receptive language skills . Reading comprehension is, according to Sari ( 2017), an activity to obtain information from written material through an interaction between the reader with the author. This means that reading comprehension is not merely expressing written language and following the text line by line, but trying to get the message and the meaning conveyed by the author. The reading process starts with decoding words through deciphering the letters that make up individual words. Then , the reader has to recognize the relationship the words have with each other. The real meaning of a text lies in recognizing these relationships and to put together the meaning of the text (Ningsih, 2017).

Kwiatkowska-White

classified comprehension into three levels including literal or factual comprehension, inferential comprehensions, and critical or evaluative comprehension. Literal or factual level refers to the simple understanding of the information that is explicitly stated. It is the second and third levels of comprehension that challenge the reader to actively engage his or her background knowledge and reasoning skills to construct meaning- meaning that is not simply stated in the written text. This makes reading comprehension a thinking task rather than simply a recall task.

\section{Reading skills}

Brown (2004) pointed out that explicit reading skills consist of two categories : microskills and macroskills. The microskills include retaining chunks of language in shortterm memory, processing writing at an efficient rate of speed, interpreting word order patterns, recognizing that a particular meaning may be expressed in different grammatical forms and recognizing cohesive devices in written discourse. On the other hand, macroskills include recognizing the rhetorical forms of written discourse, recognizing the communicative functions of a written text, inferring context by using background knowledge, distinguishing between literal and implied meanings, using different 
reading strategies and guessing the meaning of words from context.

Madani (2016) stated that reading entails several ingredients and combines various identification and interpretation skills. It involves a number of cognitive processes that help students make sense of their reading such as phonological awareness, vocabulary knowledge , background knowledge, syntactic knowledge , fluency and comprehension.

Phonological awareness is a pre reading skill. It means the ability to identify and understand the phonemes or the sounds that make words. It can also be defined as the ability to read aloud, hear, and manipulate the individual sounds within words. Vocabulary knowledge is an essential element of reading as it is considered the primary determinant of reading comprehension. There is a link between vocabulary size and reading ability. Limited vocabulary bulk could hinder learners from achieving a higher level of understanding.

Sufficient background knowledge is an essential factor for reading. Reading becomes more effective when students become able to link the reading passage to their own experiences. Learners need to be trained to connect their knowledge to the new information to help them to understand the text better. Syntactic knowledge refers to students ability to recognize the grammatical relationships between words and sentences. It involves using word order and morphological indications to understand the meaning of sentences.

Fluency is considered as an essential component of reading. Fluency in reading is the ability to read words accurately, automatically, smoothly, and quickly with little attention to mechanics of reading. Fluent readers are supposed to read accurately with speed and incorporate features of spoken and written language such as grammar and punctuation. Comprehension is a complex cognitive process that involves making logical connections between the sentences, the ideas , and the paragraphs to extract the appropriate meaning of the text. Furthermore, comprehension involves metacognition, or self- regulated thinking, which is considered as an internal interaction between the reader and the text. Reading without comprehension means nothing.

Bhlool (2013) states six types of reading: 1) oral reading which serves as an evaluation check on bottom- up processing skill, 2) silent reading that is supposed to be performed silently without labial movements or vibration of vocal cords, 3) intensive reading that attempts to focus on linguistic or semantic details of the text, 4) extensive reading that gives more concentration on the general understanding of a longer text, 5) survey reading that involves covering a large amount of text to get a general idea of its content and 6) critical reading that extends the notion of comprehension beyond simply understanding what is presented by 
linking it into existent knowledge involving evaluating what is comprehended.

Teaching reading and critical thinking skills

$\mathrm{Xu}$ (2011) proposes a five - step strategy to promote critical thinking in teaching English reading class as follows:

First step is pre-reading. In this step, teachers activate students knowledge about the topic through asking them to read the title, the first or last paragraph or topic sentence of each paragraph. Then, they ask the students to talk about their knowledge about the topic and predict the content.

Second step is comprehension of the text and explicating the main idea of each paragraph . A critical reading class should encourage students to guess or infer meaning by context clues. Teachers should encourage students to elicit the main idea of each paragraph based on their own thinking of the content.

Third step is analyzing the logic of the text. In this step, students should be encouraged to ask some questions as what is the key question the author is trying to answer? What is the author's fundamental purpose? What is the authors' point of view with respect to the issue? What information does the author use in reasoning through this issue? And what are the most fundamental inferences or conclusions in the article?

Fourth step is evaluating the logic of the text. As evaluation is one of the key critical thinking skills, assessing the logic of the reading text helps bringing reading and thinking ability to a higher level. The following questions help assess the logic of a text: Does the author clearly state his or her meaning, or is the text vague or confused? Does the author take us into the important complexities inherent in the subject, or is the writing superficial? Is the text internally consistent, or does the text contain unexplained contradictions? And is the text significant, or is the subject dealt with in a trivial manner?

Fifth step is writing. In this stage, students will be required to write summaries, commentaries, reading journals, create similar stories or composing similar style argument of their own. This step helps students to develop higher level of thinking skills - synthesis and application.

\section{Studies related to 4MAT strategy and reading skills}

To the researcher's knowledge ,only two studies were reviewed. They were Silironga (2015) and Tipayasuparat (2010). Silironga (2015) investigated the use of 4MAT strategy in enhancing students' reading comprehension process. Participants of the study were 8 students at Senior High School State Five Binjai. An introspective interview and a questionnaire of 4MAT learning styles strategy are used to collect data. Results showed that 4MAT strategy significantly enhanced the students' reading comprehension. 
Tipayasuparat

(2010)

developed a reading instructional strategy using the 4MAT System to enhance reading comprehension, vocabulary acquisition and attitude towards learning .Participants of the study were 60 second-year English majors of Faculty of Liberal Arts, Rangsit University, who had enrolled in the course: "Reading I" during the second semester of the academic year 2010. The data collecting instruments were a reading comprehension test, a vocabulary ability test and a reading attitude questionnaire. Results showed that the proposed instructional strategy enhanced students reading comprehension, vocabulary ability and promoted positive attitudes towards reading.

\section{Context of the problem}

Many EFL supervisors and teachers complain that preparatory school students have poor reading skills. They have problems with understanding both the explicit and implicit meaning of the text. Also, they lack the ability to think critically. This is due to some reasons such as they do not have a large amount of vocabulary. Also, they lack background knowledge and motivation. This is supported by several studies some of which are Sari (2017) and Madani (2016). The former observed that EFL learners face several problems in the reading process due to lack of using learning strategies and training in reading skills. The latter noticed that EFL learners have problems in reading because they do not have good mastery of grammar and they are not interested in reading.

To document the problem, the researcher conducted a pilot study. Twenty pupils from third year enrolled in Hassen Idrees preparatory school participated in the study. It consisted of a reading skill test administered to the participants. They were asked to answer some questions that measure their reading and critical thinking skills (see appendix 1). The results of the pilot study revealed that the majority $(77 \%)$ have poor reading and critical thinking skills.

\section{Statement of the problem}

In spite of the importance of reading and critical thinking skills to preparatory school pupils, they lack reading skills including the inability to infer meaning and drive meaning from context, etc. Also, they lack critical thinking skills That is why the present study attempted to help them develop their reading and critical thinking skills through using 4MAT strategy.

\section{Questions of the study}

The main question could be stated as follows:

What is the effect of using 4MAT strategy on developing preparatory school pupils' reading and their critical thinking skills?

This main question can be divided into the following sub-questions.

1. What is the effect of using 4MAT strategy on developing preparatory school pupils' literal level of comprehension? 
2. What is the effect of using 4MAT strategy on developing preparatory school pupils' inferential level of comprehension?

3. What is the effect of using 4MAT strategy on developing preparatory school pupils' critical level of comprehension?

4. What is the effect of using 4MAT strategy on developing preparatory school pupils' critical thinking skills?

\section{Hypotheses of the study}

To achieve the aim of the study, the following hypotheses were formulated:

1. There is a statistically significant difference between the experimental and the control groups' mean scores in overall reading skills post test in favor of the experimental group.

2. There is a statistically significant difference between the experimental and the control groups' mean scores in the literal level of reading skill post test in favor of the experimental group.

3. There is a statistically significant difference between the experimental and the control groups' mean scores in the inferential level of reading skill post test in favor of the experimental group.

4. There is a statistically significant difference between the experimental and the control groups' mean scores in the critical level of reading skill post test in favor of the experimental group.

5. There is a statistically significant difference between the experimental and the control groups' mean scores in the critical thinking skills post test in favor of the experimental group.

\section{Significance of the study}

The present study helps develop preparatory school pupils' reading comprehension as they are active and engaged in the reading class. This is due to addressing students' interests , needs and learning styles. Also, it directs teachers' attention to using 4MAT strategy as it considers the pupils' learning styles while teaching in general and teaching reading in particular . Finally, it might help researchers in finding new avenues of research in the field of 4MAT strategy.

\section{Delimitation of the study}

The present study is delimited to:

1.Some reading comprehension levels :literal and inferential .

2.A group of pupils $(\mathrm{N}=60)$ enrolled in Hassen Idrees preparatory school at Fayoum governorate.

3. The second semester of the academic year 2018-2019.

\section{Definition of terms \\ 4MAT strategy}

The term 4MAT strategy is used in the present study to refer to a teaching method that makes use of the four learning styles: imaginative, 
analytic, common sense and dynamic learners.

\section{Critical thinking skills}

The researcher adopted Fisher's (2001) definition as an active process of thinking and analyzing what is received.

\section{Reading comprehension skills}

The term reading comprehension skills is used in the present study to refer to the literal, inferential and critical levels with the sub skills contained preparatory school pupils should study and use.

\section{Method}

\section{A. Participants}

The participants of the current study consisted of two groups: experimental $(\mathrm{N}=30)$ and control $(\mathrm{N}$ $=30$ ). They were randomly selected from third year students enrolled in Hassen Idrees preparatory school, Fayoum governorate, Egypt.

\section{B. Design}

The researcher used the quasi experimental with experimental/control pre/post test design.

\section{Instruments and material}

To fulfill the aim of the current study, the following instruments were designed:

1- An EFL reading pre/post test

2- A critical thinking scale

3-A teacher's guide

\section{1-The EFL Reading Skills Pre-Post} Test

After making the reading skills checklist (see appendix 1) and validating it by a panel of TEFL jury members $(\mathrm{N}=5)$, the $\mathrm{EFL}$ reading skills pre/post test was prepared.

\section{1- The aim of the EFL Reading} Skills Pre-Post Test

The pre administration of the reading comprehension test aimed at measuring third year Hassen Idrees preparatory school students' reading comprehension skills before intervention. As a post test, it was used to investigate the effect of 4MAT strategy on developing the participants' reading comprehension skills.

\section{2- Description of the test}

The reading skills pre-post test consisted of a reading text selected and adapted to third year preparatory school students including two main questions: true or false sentences that measure students' literal reading skill and Wh questions that measure students' inferential and critical reading skills (see appendix 2).

\section{3- Validity of the test}

To measure the test content validity, it was given to five TEFL jury to evaluate it in terms of the extent to which the test items are adequate to measure the required skills and the suitability of the reading text and test items for the sample of the study (see appendix 3). They confirm that the test was representative of the skills that were intended to be measured and it was suitable for the study sample. Thus, the test was valid.

\section{4- Reliability of the test}

The split -half method was used to determine the reliability of the test 
. The correlation coefficient was $(0$ .75) reflecting that the test is highly reliable.

\section{5-Piloting the test}

Piloting the test aimed at determining clarity, readability and estimating the time needed for taking the test. The test was piloted on (15) pupils other than those of the main intervention. The reading test time was 35 minutes. This took place by computing the time taken by each pupil divided by the total number of the pupils(15) .

\section{2- The critical thinking scale}

\section{1- The aim of the critical thinking scale}

The scale aimed at collecting data and measuring the pupils' critical thinking skills before and after the intervention.

\section{2- Description of the scale}

The critical thinking scale consists of 25 items where the pupils were asked to underline the item(s) that indicate(s) how often they do it. The scale identifies learners' ability in summarizing, questioning, paraphrasing, researching, inferencing, discussing, classifying, outlining, comparing and contrasting, distinguishing and reasoning. The participants were asked to rate the frequency of each category on a 3point Likert-scale, ranging from never, sometimes, to always (1-3) points, respectively (see appendix 4).

\section{3- Validity of the scale}

To estimate validity, the scale was submitted to a panel of jury members $(\mathrm{N}=5)$. They indicated that the scale is valid after making the modifications required.

\section{4-Reliability of the scale}

The split -half method was used to determine the reliability of the scale. The correlation coefficient was $\left(\begin{array}{ll}0 & .72\end{array}\right)$ reflecting that the scale is highly reliable.

3- A teacher's guide for teaching reading through $4 \mathrm{MAT}$ strategy

3.1- Aim and objectives of the manual

The manual aimed to help preparatory school teachers teach reading and critical thinking skills through 4MAT strategy. It could also and guide them while teaching reading to preparatory school pupils (see appendix 5).

\section{Objectives}

By the end of the teacher's guide sessions, pupils will be able to:

-recognize general idea.

-recognize supporting details.

-express their opinions about various situations in the reading passage.

-suggest another topic to the lesson.

-infer the implicit meaning of the passage.

- predict what the text is about.

-evaluate different event and characters in the reading passage.

-compare and contrast different events.

-pass judgment.

-differentiate between similar events. 


\section{2-Content}

The researcher adapted the English lessons of the second semester of the academic year $2018 / 2019$ to be taught via 4MAT strategy. The researcher prepared suitable activities for the four styles of learners: imaginative, analytic ,common sense and dynamic. Thus, they had the opportunity to learn through the preferred learning styles. The sessions were shown in the following table:

Table (1) Sessions of the teacher's guide

\begin{tabular}{|l|l|}
\hline Sessions & \multicolumn{1}{|c|}{ Title } \\
\hline $1-$ & Pre testing \\
\hline $2-$ & An introductory session \\
\hline $3-$ & Technical schools \\
\hline $4-$ & New wonders of the world \\
\hline $5-$ & Digital projects \\
\hline $6-$ & Animal life in the past \\
\hline $7-$ & Khaled's blog \\
\hline $8-$ & ThtThe Red Sea \\
\hline $9-$ & t te Post testing \\
\hline
\end{tabular}

These sessions were seven in addition to one for pre testing and one for post testing. The total number of the sessions were 9 .

\section{3- Techniques and activities}

Various individual, pair and group work activities were used in each session. The activities were designed in a way that is relevant to pupils' learning styles. In each session, the researcher presented the purpose of each activity and assisted pupils through providing them with cards and guidelines for doing the activity.

\section{4-Evaluation}

Two types of evaluation were used: formative and summative. Formative evaluation was represented in the questions, activities and quizzes pupils were asked to answer during the lessons while summative evaluation was represented in the reading skills post test.

\section{Experimental procedures} 1-Pre-testing

Students' pre-testing of the reading skills test took place on $23^{\text {rd }}$ February 2019. This was done to identify the students' entry level before the intervention. Also, the critical thinking scale was administered to measure pupils' critical thinking skills.

\section{2- Teaching sessions}

The experimental group pupils were taught using 4MAT strategy. There were 7 sessions devoted to enhancing the experimental group pupils' reading and critical thinking skills. They began on $6^{\text {th }}$ 
March 2019 and ended on $24^{\text {th }}$ April 2019.

In the first session the researcher introduced 4MAT strategy to the pupils and explained what they were going to do. Then, she trained them in reading and critical thinking skills following the 4MAT strategy providing suitable activities for the four learning styles of learners. The researcher devoted the class time for explanation, discussion, pair and group work and feedback . Pupils were encouraged to initiate, speak and interact actively.

\section{3-Post-testing}

At the end of the intervention, the researcher evaluated pupils' progress through administering the reading post-test and the critical thinking scale. This was done to investigate the effect of 4MAT strategy on developing preparatory school pupils' reading as well as their critical thinking skills.

Data were treated statistically and the results and discussion will be dealt with in the following section.

\section{Findings of the study:}

The findings of the present study are presented in the light of the hypotheses using the statistical package for social sciences (SPSS).

\section{1-The first hypothesis}

The first hypothesis states that " There is a statistically significant difference between the experimental and the control groups' mean scores in overall reading skills post test in favor of the experimental group ".

Table (2) significance of the experimental and control groups' difference in the post administrations of overall EFL reading skills.

\begin{tabular}{|c|c|c|c|c|c|c|c|}
\hline Group & N & Mean & S.D & T-Value & D.F & Sig. & Effect size \\
\hline Experimental & 30 & 7.74 & 3.21 & \multirow{2}{*}{5.52} & \multirow{2}{*}{58} & 0.01 & 0.92 \\
\hline Control & 30 & 4.75 & 2.21 & & & & \\
\hline
\end{tabular}

Table (2) shows that experimental group pupils' posttest scores are significantly higher than the control group ones in overall reading skills. They attained a higher mean score in the posttest(7.74) than that of the control group (4.75). T value is (5.52) and this difference is significant at (.01) level .Thus, the first hypothesis of the study was

supported. The effect size was ( 0.92) proving high effect.

\section{2-The second hypothesis}

The second hypothesis states that " There is a statistically significant difference between the experimental and the control groups' mean scores in the literal level of reading skill post test in favor of the experimental group".

Table (3) inferential in the post administration of the reading skill test (literal level).

\begin{tabular}{|c|c|c|c|c|c|c|}
\hline Group & N & Mean & S.D & T-Value & D.F & Sig. \\
\hline Experimental & 30 & 5.34 & 2.23 & \multirow{2}{*}{5.45} & \multirow{2}{*}{58} & \multirow{2}{*}{0.01} \\
\hline Control & 30 & 3.04 & 1.60 & & & \\
\hline
\end{tabular}


Table (3) shows that experimental group pupils' posttest scores are significantly higher than the control group ones in the literal level of reading skill. They attained a higher mean score in the posttest(5.34) than that of the control group (3.04). $\mathrm{T}$ - value is (5.45) and this difference is significant at (.01) level .Thus, the second hypothesis of the study was supported.

\section{3-The third hypothesis}

The third hypothesis states that " There is a statistically significant difference between the experimental and the control groups' mean scores in the inferential level of reading skill post test in favor of the experimental group".

Table (4) significance of the experimental and control groups' difference in the post administration of the reading skill test (inferential level).

\begin{tabular}{|c|c|c|c|c|c|c|}
\hline Group & N & Mean & S.D & T-Value & D.F & Sig. \\
\hline Experimental & 30 & 6.20 & 2.25 & \multirow{2}{*}{5.62} & \multirow{2}{*}{58} & \multirow{2}{*}{0.01} \\
\hline Control & 30 & 3.49 & 1.85 & & & \\
\hline
\end{tabular}

Table (4) shows that experimental group pupils' posttest scores are significantly higher than the control group ones in the inferential level of reading skill. They attained a higher mean score in the posttest (6.20) than that of the control group (3.49). $\mathrm{T}$ - value is (5.62) and this difference is significant at (.01)

level .Thus, the third hypothesis of the study was supported.

\section{4-The fourth hypothesis}

The fourth hypothesis states that " There is a statistically significant difference between the experimental and the control groups' mean scores in the critical level of reading skill post test in favor of the experimental group".

Table (4) significance of the experimental and control groups' difference in the post administration of the reading skill test (critical level).

\begin{tabular}{|l|c|l|l|c|c|c|}
\hline Group & $\mathrm{N}$ & Mean & S.D & T-Value & D.F & Sig. \\
\cline { 1 - 4 } Experimental & 30 & 19.27 & 4.35 & \multirow{2}{*}{9.67} & \multirow{2}{*}{58} & \multirow{2}{*}{0.01} \\
\hline Control & 30 & 11.09 & 3.34 & & & \\
\hline
\end{tabular}

Table (4) shows that experimental group pupils' posttest scores are significantly higher than the control group ones in the critical level of reading skill. They attained a higher mean score in the posttest (19.27) than that of the control group (11.09). $\mathrm{T}$ - value is (9.67) and this difference is significant at (.01) level .Thus, the fourth hypothesis of the study was supported.

\section{5-The fifth hypothesis}

The fifth hypothesis states that " There is a statistically significant difference between the experimental and the control groups' mean scores in the post administration of the critical thinking scale in favor of the experimental group". 
Table (5) significance of the experimental and control groups' difference in the post administration of the critical thinking scale.

\begin{tabular}{|l|c|l|l|c|c|c|c|}
\hline \multicolumn{1}{|c|}{ Group } & N & \multicolumn{1}{|c|}{ Mean } & S.D & T-Value & D.F & Sig. & Effect Size \\
\cline { 1 - 6 } Experimental & 30 & 25.66 & 1.41 & 48.92 & 58 & 0.01 & 0.98 \\
\hline Control & 30 & 11.14 & 1.83 & & & & \\
\hline
\end{tabular}

Table (5) shows that the experimental group pupils' scores are significantly higher than the control group ones in the post administration of critical thinking scale. They attained a higher mean score in the post measuring (25.66) than that of the control group (11.4). $\mathrm{T}$ - value is (48.92) and this difference is significant at (.01) level. Effect size was (0.98) proving high effect. Thus, the fifth hypothesis of the study was supported.

\section{Discussion of the Results}

The aim of the present study was to develop third year preparatory school students' reading and critical thinking skills using 4MAT strategy. The experimental group improvement in the reading skills was not only in the overall reading skills, but also in each reading skill/component of the reading skills. This is due to the advantages of 4MAT strategy that helped learners to learn according to their learning styles facilitating their learning. In addition, they were involved in pair as well as group work activities and receive various types of feedback.

$$
\text { 4MAT strategy provides a }
$$
student - centered learning environment based on their learning styles and needs considering their individual differences. It promotes student-student and teacher - student interaction. The experimental group pupils confirmed that 4MAT strategy makes the learning process more enjoyable, motivating, excited and interesting because the classroom activities address their needs and expectations reducing their anxiety and stress. Also, it helped them connect new information to previously learned information, analyze and practice new information as well as deepen their information about the new lessons through reading about other related issues.

Moreover, there is a significant and positive relationship between pupils' scores in reading skills and their critical thinking skills. Addressing pupils' learning styles through the use of the 4MAT strategy boosts the experimental group pupils' critical thinking skills. The use of critical thinking skills fosters the sense of responsibility for pupils' learning and encourages them take charge of their own thinking.

Promoting critical thinking skills is considered one of the tasks of language teachers. Teachers should train students in the use of these skills, encouraging them to analyze, organize and formulate new information accurately and precisely. Teachers should prepare effective questions, select challenging and motivating topics and respect different viewpoints 
to provide pupils with a meaningful critical thinking environment. Also, test items should not only focus on memorization questions but they should also include critical thinking provoking questions.

The results of the study revealed that 4MAT strategy proved to have a high effect on developing students' overall reading skills and their critical thinking skills. These results are in line with the findings of Silironga (2015) that aimed at investigating the use of 4MAT strategy in enhancing students' reading comprehension process and concluded that 4MAT strategy significantly enhanced the students' reading comprehension. Also, they agree with those of Khaoanurak (2015) that aimed at investigating the use of 4MAT strategy in improving students' critical thinking in English reading class and concluded 4MAT strategy improved students' critical thinking and motivated them to learn English.

\section{Conclusion}

The results of the study showed that experimental group pupils' reading and critical thinking skills were improved after the use of 4MAT strategy. Therefore, the significant differences were in favour of the experimental group pupils. This can be ascribed to the implementation of 4MAT strategy.

\section{Recommendations of the study}

In the light of previous results, the following recommendations could be presented:
1.Curriculum designers should give top priority to the 4MAT strategy when designing English courses.

2.Enriching the curriculum with similar methods that address students' learning styles.

3.EFL teachers should receive preservice and in-service and training to help them use 4MAT strategy in teaching different language skills.

$$
\begin{aligned}
& \text { 4.4MAT strategy should be } \\
& \text { emphasized in } \\
& \text { educational stages. }
\end{aligned}
$$

\section{Suggestions for further research}

Based on the findings of the current study the following suggestions are presented.

1-Investigating the effect of 4MAT strategy on developing other language skills such as writing and speaking.

2-The effect of using 4MAT strategy on learners' self- learning skills and motivation to learn.

3- Using 4MAT strategy to integrate several language skills.

4-Investigating the effect of other learning styles strategies on developing reading comprehension.

\section{References}

Bhlool , A. (2013). The Effect of Differentiated Instruction Strategy on Developing Ninth Graders' English Reading Comprehension Skills at Gaza UNRWA Schools. Unpublished MA. Thesis . Faculty of Education. The Islamic University of Gaza. 
BulBul, H. \& Ozsoy, V. (2015). Students views on the 4MAT strategy application in the two dimensional art studio classes in the fine arts high school. Anadolu Journal of Educational Sciences International , Art Education Special Issue. Retrieved from: http://www.researchgate.net/pu blication/294106459.pdf.

Brown, D. (2004). Language assessment principles and classroom practices. New York: Pearson Education Ltd.

Fahim, M. \& Pezeshki, M. (2012) . Manipulation critical thinking skills in test taking. International Journal of Education, 4 ( 1), 153 - 160.

Fisher, A. (2001). Critical thinking : An introduction. Cambridge: Cambridge university press.

Ghaemiy H. \& Taherian, R. (2011). The role of critical thinking in EFL teachers' teaching success. MJAL, 3 (1), 8- 22.

Irfan, O. ; Alufadi, F. \& Brisha, A. (2016). Effect of using 4 MAT method on academic achievement and critical thinking toward engineering economy for undergraduate students. International Journal of Vocational and Technical Education, 8 (1), 1- 11.

Khaoanurak, N. (2015). Effectiveness of the 4MAT Strategy in Enhancing Students' Critical Thinking Skills in English Reading Classes. Unpublished MA.
Thesis. Retrieved from http://cmuir.cmu.ac.th/handle/66 53943832/39754.pdf.

Kutay, H. (2006). A Comparative Study about Learning Styles Preferences of Two Cultures. Unpublished Ph.D. Dissertation . College of Education. Ohio State University.

Kwiatknowska-White, B. (2012). Understanding Reading Comprehension Performance in High School Students. Unpublished Ph.D. Faculty of Education . Queen's University. Canada.

Lakovos, T. (2011). Critical and creative thinking in the English language classroom. International Journal of Humanities and Social Sciences, (8) , 82- 86.

Madani, H. ( 2016) . The Effect of Reading Skills on the Development of Language Proficiency. Unpublished Ph.D. Dissertation. Faculty of Letters and Languages . University of Abou Bakr Belkaid - Tlemcen.

Muirhead, B. (2002). Integrating critical thinking into online classes. USDLA Journal, 16 (11), 82- 85.

Nicoll - Senfl, J. \& Seider, S. (2010). Assessing the impact of the 4 MAT teaching strategy across multiple disciplines in higher education. College Teaching Journal, 58 , 19- 27.

Nigsih, S. (2017) . Improving the Students' Ability in Reading 
Comprehension of Narrative Text through Question Answer Relationship at the Tenth Grade of Man Binjai . Unpublished S. Thesis. Faculty of Tarbiyan Science and Teachers Training. State Islamic University of North Sumatera.

Nugent, P \& Vitale, B. (2008) . Fundamental success: A course review applying critical thinking to test taking. USA: F.A. Davis company.

Pelteret, C. (2019) . New Hello ! English for preparatory schools. Egypt : Egyptian International Publishing Co. Longman.

Rezaei , S. ; Derakhshan, A. \& Bagherkazemi, M. (2011). Critical thinking in language education. International Journal of Language Teaching and Research, 2 (4) , 769 - 777.

Sari, L. (2017) . Improving Reading Comprehension through Directed Reading Thinking Activity (DRTA) Strategy for the Eight Grade Students as SMP Negeri 17 Medan in the Academic Year of 2016- 2017. Unpublished S. Thesis . Faculty of Tarbiyan Science and Teachers Training. State Islamic University of North Sumatera.

Şeker, B. \& Övez, F. (2018). The integration of the 4MAT teaching strategy with the interdisciplinary structure: A new strategy proposal and text
. Eurasia J. Math Sci and Tech Ed, 14 (5), $1767-1790$.

Shirkhani, S. \& Fahim, M. (2011). Enhancing critical thinking in foreign language learners. Procedia- Social and Behavioral Sciences, 29 , 111- 115.

Silironga, R. (2015). Improving Students Reading Comprehension Process By Using The 4MAT Learning Strategy. Explora Journal of English Language Teaching and Linguistics. Retrieved from https://uhn.ac.id/files/akademik files/1712080250 2015.pdf.

Tezcan, G. \& Guvenc, H. (2017). The effects of 4MAT teaching strategy and whole brain strategy on academic achievement in science. Education and Science, 42 (192), 303- 325.

Tipayasuparat, N. (2010). Development of a Reading Instructional Strategy Using the 4MAT System and Music to Enhance Vocabulary Acquisition for English Reading Comprehension and Attitude Towards Learning of Undergraduate Students. Unpublished Ph.D. Dissertation .Faculty of Education. Chulalongkorn University

Uyangor , S. (2012). The effectiveness of the 4MAT teaching strategy upon student achievement and critical thinking levels. International of Research Studies in Education, 1 (2), 43 - 53. 
Yu, J. (2011). The application of critical thinking in teaching English reading. Theory and Practical in Language Studies, $1(2), 136-141$.
Zhang, L. \& Kim, S. (2018). Critical thinking cultivation in Chinese college English classes. English Language Teaching, 11 (8) , 159- 164 